\title{
Common scale insects (Hemiptera:Coccoidea) in Egypt
}

\author{
Hassan, N. A.; Radwan, S. G. and El-Sahn, O. M.N. \\ Plant Protection Research Institute, Agriculture Research Center, Dokki, Giza, Egypt
}

\section{ABSTRACT}

The scale insects are small insects of the order Hemiptera, generally classified as the Superfamily Coccoidea. There are about 8,000 species of scale insects. Scale insects feed on a wide variety of plants, and scale species are considered pests. This review article is presenting the ecological aspects of some important scale insects and mealybugs infesting horticulture plants in Egypt. Armored scale insects (Hemiptera: Diaspididae) like Aulacaspis tubercularis Newstead, Pseudaulacaspis pentagona (Targioni-Tozzetti ), Parlatoria oleae (Cloveé), Parlatoria ziziphi (Lucas), Fiorinia phoenicis Balachowsky and Hemiberlisia lataniae (Signoret). While, the soft scale insects (Hemiptera: Coccidae) showed by Pulvinaria tenuivalvata (Newstead), Pulvinaria psidii Mask., Saissetia_coffeae (Walker) and Ceroplastes floridensis Comstock. In case of mealybugs was represented with Planococcus ficus (Signoret) (Hemiptera: Pseudococcidae), Icerya seychellarum (Westwood) (Hemiptera: Monophelibidae) and Ferrisia virgata (Cockerell) (Hemiptera: Pseudococcidae). Family: Asterolecaniidae exampled by Asterolecanium pustulans Ck1l. (Hemiptera: Asterolecaniidae).

Keywords: Common scale insects, Egypt

\section{INTRODUCTION}

Scale insects found in different parts of the world fall within 23 Families while only 12 out of that number are found in Egypt. The most important of these are 3 families being armored scale insects (Diaspididae), mealybugs (Margarodidae and Pseudococcidae) and soft scale (Coccidae) and these are dangerous species that attack different important economic crops in Egypt. Most of the species belongs of these families are polyphagous, eurymerous, and attack various parts of the host plant, leaves, stem, bark, crown, fruits and roots. The main injury caused due to their ingestion of plant sap, reduction of plant vigor, drop leaves or spottily yellowing, deformation of shoot and twig, blister like galls, fruit drops and affect on the normal physiological activities of the trees with effect on nitrogen, protein, phosphorus, potassium, calcium, magnesium, chlorophyll "a" and "b".

\section{RESULTS}

\section{Armored scale insects (Hemiptera: Diaspididae)}

Family Diaspididae represent the largest family which includes major pests in Egypt (Ghabbour and Mohammad, 1996), they listed 72 species of this family in Egypt. The armored scales are smaller on the average than the unarmored scales, they may be circular, subcircular, elongate, thread like or may assume a characteristic oyster shell shape. The segmentation of adult female's body is obscure. The head and thorax are fused. The antennae are absent or restigial, the eyes and legs are absent. Two pairs of thoracic spiracles are present, but there are no abdominal spiracles. The 
wax is secreted by the wax glands of the pygidium. The exuvia are added to the armor during molting. The body not attached to the armor between molts, the young of armored scale insects are either born alive or hatched form eggs (oviparous).

\section{The most important scales belong to this family are:}

\section{1) Aulacaspis tubercularis Newstead}

The mango scale, A. tubercularis is presently a wide spread pest throughout all mango trees in Egypt causing severe damage to leaves and dryness of branches. Radwan (2003) recorded that, A. tubercularis are present on mango trees all over the year. The main activity period for the total population took place in the first May until mid of September and the lowest population of this insect was recorded during middle of September. It has three overlapping generations per year. The third generation was the biggest which extended from the first August to end of December ( 5 months) in the first studied year, and recorded from the first of September to the end of December (4 months) in the second. The combined effect of the weather factors on the activity of $A$. tubercularis and their total population were potency and ranged between 19.5-42.7\%. Mohamed (2010) surveyed the most injurious scale insects on mango trees at Qaliobiya Governorate (El-Khanka, Shebeen El-Qanater, Banha \& ElQanater) from August 2005 to July 2007. It is clear that: the most abundant scale insect pest was: the hard scale A. tubercularis forming (28.67\%) of the all collected species and represented from all localities.

\section{2- Pseudaulacaspis pentagona (Targioni-Tozzetti):}

Peach orchards infested with numerous pests among of which scale insects especially armored scale insect; the white peach scale attacks branches and twigs, it sucks a great amount of sap causing dry branches and defoliation of leaves. Also, twigs are killed as a result of infestation and defoliation of peach fruits. P. pentagona total population recorded five peaks, the first between February and March, the second between April and May, the third recorded in July, the fourth in November while the fifth between December and January. Also, this insect has four depressive periods during March, August, November and January. P. pentagona has 3 annual generations the first was present from approximately (April - July), the $2^{\text {nd }}$ from July to September and the third in September, over wintering as a gravid females (Kreiter et al., 1997), while Atteya (2004) recorded 5 generations were recorded on mid March, early May, July, mid August and in October.

\section{3- Parlatoria oleae (Cloveé):}

$P$. oleae mainly infests deciduous fruit trees branches and fruits as well as ever green trees as olive. The insect is a major pest on pear, apple, plum, apricot and olive. El-Hakim and Helmy (1982) in Egypt mentioned that P. oleae had three peaks in Cairo and Fayoum, and two peaks in Alexandria on olive trees. two generations of $P$. oleae was recorded a year on plum and peach in Beheira. (Kasim, (1995), while Asfoor (1997), reported three generations of P. oleae annually on pear trees in Qalyobia Governorate, but only two generations on plum, pear and apple trees. recorded three annual peak on Hollywood plum, maribosa plum, apricot and peach these peaks occurred in May, August and October. She, also, indicated three generations on four deciduous trees the , the first generation appeared on first May, the second appeared on first August and the third generation appeared on first October (Ezz, 1997).

\section{4- Parlatoria ziziphi (Lucas)} and fruits.

$P$. ziziphi is consider an important pest on citrus and it attacks leaves, branches 
The seasonal variation in the population of $P$. ziziphi on sour orange leaves at Giza region during 1982 and 1983. The insect had two peaks of activity per year in April and October (El Bolok et al., 1985).

Sweilm et al. (1985) studied the biology of $P$. ziziphi on sour orange trees in Egypt under field and laboratory conditions. The scale had 2 generations a year. Salama et al., (1985) reported that P. ziziphi on grape fruit in Egypt had two annual peaks of abundance in Sept. and May and there were 3 generations a year in Sept.Oct., Mar.-Apr. and Jun.-Jul. P. ziziphi had 2-3 annual generations begin in Jun., Oct. and Apr. to May (Serag,1997). Helmy (2000) stated three generations of P. ziziphi a year on four citrus varieties (i.e. mandarin, baladi orange, grape fruit, and trifoliate orange trees). Peaks occurred in Apr., Aug. and Oct.

\section{5- Fiorinia phoenicis Balachowsky}

In the last few years, scale insect was observed with high numbers on date palm fronds and dates in some governorates in Egypt causing yellowish of the pinnae and dryness of the fronds as well as the infested dates becomes unmarketable and has a large grade. F. phoenicis a new pest on date palm in Egypt (Ghabbour and Mohammad, 2010). Elwan et al. (2011) studied the seasonal activity of F. phoenicis. They found that, the scale insect had three overlapping generations under field conditions. The first generation (early summer generation) peaked in early June and the 2nd generation (late summer generation) peaked around August/September whereas the 3rd generation (autumn generation) peaked in October / November. The shortest generation was the late summer generation $\left(2.5-3.0\right.$ months) at $27.9-28.6^{\circ} \mathrm{C}$ and $63.5-64.8 \%$ R.H. whereas the longest one was autumn generation (4.5 months) at $21.6-22.0^{\circ} \mathrm{C}$ and $65.9-66.3 \%$ R.H. The early summer generation had intermediate duration (4.0 -4.5 months) at $20.9^{\circ} \mathrm{C}$ and $62.5 \%$ R.H. in the two years, respectively. The insect population occurred on date palm fronds all the year round and decreased to lower numbers during winter season and this referred to the cold weather. The basal stratum of date palm leaflets received the highest infestation $(37.4-38.3 \%)$ than middle (34.4-35.3\%) and apical ones (26.4 - 28.2\%).

6- Hemiberlisia lataniae (Signoret)

Salama and Hamdy (1974) stated that $H$. lataniae had a peak of abundance in September and passed through two annual generations. $H$. lataniae is widely distributed and attacks many species of host plants. Field observation revealed that it is principal scale pest of Ficus sp. trees and other ornamental and orchards like Acacia Arabica, Morus sp., Psidium guajava, Olea europaea and Prunus domestica. This scale inesct had two generations per year where the first generation crawlers appearing from mid-June to mid-July and second generation crawlers appearing in September. In Egypt, there are two to four generations per year (Hassan, 1993). Tawfik and Mohammad (2001) H. lataniae had four population peaks during the year on Morus alba in Giza Governorate.

\section{Mealybugs:}

The second largest family, it has 47 species of mealybug belong to 28 genera (Nada, 1999). The mealybugs (Family: Pseudococcidae), especially those of the genus Pseudococcus, are widely distributed throughout the world on ornamental plants and orchards. They occur on a large number of hosts, but in temperature regions they are found mainly in greenhouses. They have soft, oval, flattened, distinctly segmented bodies. They are covered with white, mealy wax and usually with lateral waxy filaments. They cause injury by extracting plant sap and by excreting honeydew, which forms a medium for the growth of sooty mold fungus. They may cause fruits drop when they cluster about the fruit stems. 


\section{1-Planococcus ficus (Signoret) (Hemiptera: Pseudococcidae)}

The pseudococcid, $P$. ficus is a very important one, as through the feeding activity of its nymphs and adults, direct damage to clusters is caused. Moreover, during its feeding on the different parts of the plant, excretes honey dew that supports the growth of sooty mould. Sooty and sticky bunches harboring mealybugs individuals and their white cottony wax masses tend to be inferior in the marketing value as table grapes, and raisins cannot be prepared from such infested bunches. In addition to this obvious damage, $P$. ficus as well as the other species of mealybug are capable of transmitting grape vine leafroll from plant to another (Attia ,2003). The individuals of mealybugs were found throughout the year beneath the bark, infestation with $P$. ficus began in mid April and appeared in mid June. The most active period covered from mid August to October $1^{\text {st }}$ showing the highest peak. She also, mentioned that,the population of mealybugs on root showed in February $1^{\text {st }}$. The decrease of mealybug individuals after this date referred to the movement of individuals from roots to trunks.

\section{2-Icerya seychellarum (Westwood) (Hemiptera: Monophlebidae)}

In recent year, I. seychellarum become established and increased in Egypt. Tawfik and Mohammad (2001) recorded I. seychellarum on Morus alba in Giza Governorate and had two peaks. El-Serafi et al.,(2004) found I. seychellarum on guava trees at Mansoura district. Hassan and Radwan (2008) detected that, the incandescent population of all stages of I. sychellarum on persimmon (Diospyros kaki) through August and summer convenient season for I. seychellarum activity in contract winter and spring were inept for its activity so population infirmly were shown. It has four overlapping generations on kaki trees.

\section{3-Ferrisia virgata (Cockerell) (Hemiptera : Pseudococcidae)}

Abd El-Said (1997) studied F. virgata population density of $F$. virgata was studied at Giza region on two host plant shrubs; Acalypha macrophylla and Lantana camara. The nymphs of $F$. viragata on the first host increased gradually from $1^{\text {st }}$ July until reaching the first peak on September $1^{\text {st }}$ and the second peak was in October $1^{\text {st }}$. While on lantana shrub population density of Ferrisia nymphs increased gradually from $1^{\text {st }}$ July till $1^{\text {st }}$ peak on September $15^{\text {th }}$ and the $2^{\text {nd }}$ peak was in $15^{\text {th }}$ of October. Which means that F. virgata has two annual generations on the both hosts. Balboul (2003) mentioned that $F$. virgata individual insects of $1^{\text {st }}$ generation appeared during the first half of November and the first peak was recorded in the middle of December, while the second generation occurred during the period extending from about first half of June and the second peak was recorded in the middle of October.

\section{Soft scale insect) (Hemiptera: Coccidae):}

The third largest family of scale insects (Hamons and Williams, 1984), Family Coccidae represented by number of species of unarmored or soft scales, they have widely spread on orchards and ornamental plants with importance as armored scales. The unarmored scales as their name implies not posses the scale covering or "armor", their bodies are relatively soft in the younger instars but the mature females may possess a derm which together with its waxy secretions, segmentation is indistinct also antennae and legs are usually present after the first instar.

\section{1-Pulvinaria tenuivalvata (Newstead):}

$P$. tenuivalvata become one of the most important pest infesting sugar cane in Egypt especially in Qena Governorate. It attacks the sugar cane leaves causing serious damage and noticeable reduction in the yield. $P$. tenuivalvata emerged as a chronic pest of sugar cane plants at_Giza, Beni Sweif and Qena Governorates (Haries, 2006). Helmy et al., (2001) stated that, over the last five years P. tenuivalvata became one of 
the most important pest infesting sugar cane especially in Qena Governorate. Helmy (2001) found that sugar cane soft scale insect $P$. tenuivalvata is the most important pest infesting sugar cane in El-Saff district, Giza Governorate It has five peaks of abundance in each season Concerning $P$. tenuivalvata different stages nymphs has two small peaks in mid February and early June followed by three other peaks on early August, September and the fifth and highest peak was on mid October. It had five overlapping generations on the sugar cane plants.

\section{2-Pulvinaria psidii Mask.:}

$P$. psidii is the most important pest on mango and guava growers. Insects attack trees and result in a poor crop of poor quality and quantity. The insects secrets honey dew to cover the upper surface of the leaves and prevents the photosynthesis and respiration. Pre adults of $P$. psidii were found all over the year and the greatest of $P$. psidii were recorded during November, December and January El-Minshawy et al., (1974). Hendawy (1999) mentioned that the total number of nymphs and adult females of P. psidii on guava has two peaks on November and August. Radwan (2003) recorded that, $P$. psidii were achieved three peaks on mango trees at the first of April, first of September and mid of November and had four overlapped generation per year. Also, $P$. psidii recorded highest population density on guava trees at first of December and had four overlapping generation per year. P. psidii had three annual peaks on guava trees at Qaluobiya Governorate which achieved at 1st May, 1st August and mid October (Mohammad, 2010). Elwan, et al. (2011) mentioned that, the population dynamics of the green shield scale, $P$. psidii on guava, occurred on guava trees all the year round and has two overlapping generations a year.

\section{3- Saissetia coffeae (Walker)}

In Egypt it is consider as the most serious pest attacking guava, olive and latania palms (Hassan, 1993).this pest sucks the sap and causes dry up of leaves and small branches. it also, secretes honey dew on which the black fungus grow up which result a reduction in both yield and marketing value of the fruits. Three peaks of abundant of S. coffeae were recordrd on Cycas revoluta in El-Zohreya Botanical Garden Giza Governorate The highest peak was in March with 1210.10 individuals/10 leaflets with maximum temperature $\left(23.45^{\circ} \mathrm{C}\right)$, minimum temp. $\left(13.84{ }^{\circ} \mathrm{C}\right)$ and Relative humidity \% (54.18\%). While the lowest population was recorded from mid August till the end of October (El-Sahn, 2007).

\section{4- Ceroplastes floridensis Comstock}

C. floridensis recorded for the first time on orange trees near Alexandria in 1905 (Willcocks, 1922). It has three peaks, the first peak occurred at April, the second peak at June and the third at November. The third peak was the highest one while the first was the lowest. The population of $C$. floridensis showed two peaks only on grape fruit (El-Imery, 1985).

\section{Family: Asterolecaniidae}

\section{Asterolecanium pustulans Ckll. (Hemiptera:Asterolecaniidae)}

A. pustulans are major pests of fig trees in Burg El-Arab. The former species had two generations, the first about four months from January till the end of April, while the second generation took about 3 months from the beginning of October till the end of December (Eraki, 1991).

\section{REFERENCES}

Abd- El-Said, A.R. (1997): Ecological and biological studies on mealybug parasitoids at Giza region. M.Sc. Thesis, Fac. Agric., Cairo Univ. 
Attia, A.R.A. (2003): Ecological and biological studies on the vine mealybug, Planococcus ficus (Signoret) and its associated parasitoids. Ph.D. Thesis, Fac. Agric., Cairo Univ., 262pp.

Atteya, S. A. (2004): Ecological and toxicological studies on the white peach scale insect Pseudaulacaspis pentagona in Dakahliya Governorate . Mc.S. Thesis, Fac. Sci., Benha Branch, Zagazig Univ., 98pp.

Balboul, O.A. H. (2003): Ecological safe ways for controlling some insect pests attacking the guava trees at Giza Governorate. M.Sc. Thesis, Dept. Agric. Sci., Institute Environ. Studies and Res., Ain Shams Univ.,148pp.

Eraki, M.M. (1991): Ecological studies on certain scale insects infesting fig trees. M.Sc. Thesis, Fac. Agric., Al-Azhar Univ.

Asfoor, M. A. (1997): Seasonal abundance and control of plum scale insect Parlatoria oleae (Cloveé) on some deciduous trees. Ph.D. Thesis, Fac. Agric., Zagazig Univ., Egypt, 398 pp.

El-Bolok, M.M.; Sweilem, S.M. and Abdel Aleem, R.Y. (1985): Seasonal variation in the population of Parlatoria zizyphus (Lucas) at Giza region. Bull. Soc. Entomol., Egypt, 65:281-288.

El-Hakim, A.M. and Helmy, E.I. (1982): Survey and population studies on olive leaf pests in Egypt. Bull. Entomol. Soc., Egypt, 64:213-220.

El-Imery, S.M.M. (1985): Studies of certain ecological factors and their relation to the chemical control of the wax scale insect Ceroplastes floridensis (Comstock) on citrus plant in Egypt. M.Sc. Thesis, Fac. Agric., Ain Shams Univ.,105pp.

El-Minshawy, A.M.; Hammad, S.M. and Moursi, K.H. (1974): Seasonal abundance of scale insects and mealybugs attacking guava trees in Alexandria district. $2^{\text {nd }}$ Egypt. Pest. Conf., Alexandria, 571-586.

El-Sahn, O.M.N. (2007): Studies on Parlatoria pergandii Comstock and Saissetia coffeae (Walker) infesting certain ornamental plants. Ph.D. Thesis, Fac. Agric., Cairo Univ.,251pp

El-Serafi, H. A.; Ghanim, A. A.; El-Heneidy, A. H. and El-Sherbenie, M. K. (2001): Ecological studies on certain insects infesting guava orchards and their predatory insects at Mansoura District. Egypt. J. Biological Pest Control, 14: (1) 77-85.

Elwan, E.A.; El-Sayed, M.I. and Serag, A.M. (2011a): Seasonal activity of Fiorinia date scale, Fiorinia phoenicis Balachowsky (Hemiptera: Diaspididae) on date at Giza Governorate, Egypt. Egypt. J. Agric. Res., 89 (2):549-565.

Elwan, E.A.; Serag, A.M. and El-Sayed, M.I. (2011b): Population dynamics of the green shield scale, Pulvinaria psidii (Hemiptera: Coccidae) on guava trees at Shibin El Qanater district, Qalubiya Governorate, Egypt. Egypt. J. Agric. Res., 89 (2):535-548.

Ezz, N. A. (1997): Ecological studies on plum scale insect Parlatoria oleae and its parasitoid Aphytis sp. on deciduous trees. M.Sc. Thesis, Fac. Agric., Cairo Univ., $1498 \mathrm{pp}$.

Ghabbour, M. W. and Mohammed, Z.K. (1996): The Diaspididae of Egypt (Coccoidea : Homoptera). J. Egypt. Ger. Soc. Zool., 21 (E): 337-369.

Hamons, A.B. and Williams, M.L. (1984): The soft scale insects of Florida (Homoptera : Coccoidea : Coccidae) arthropods of Florida and neighboring land area. Florida Department of Agicultures consumer services, Division of plant industry, 195pp. 
Haries, H. M. A. (2006): Integrated management of the soft scale insect infesting sugar-cane in Qena Governorate. M.Sc. Thesis., Fac. Agric., Ain Shams Univ., $137 \mathrm{pp}$.

Ghabbour, M. W. and Mohammad, Z. K. (2010): Fiorinia phoenicis (Hemiptera : Coccoidea :Diaspididae) new pest of palm trees in Egypt. J. Egypt. Ger. Soc. Zool., 58(E): Enotomology, 15-20.

Mohammed, S. A. A. (2010): Ecological studies of scale insects infesting mango and guava trees and their control in Qaluobiya Governorate. Ph.D. Thesis, Fac. Sci., Ain Shams Univ., 216pp.

Hassan, N.A. (1993): Survey and toxicological studies on citrus diaspine scale insects and their parasites in Egypt. Ph.D. Thesis, Fac. Sci., Ain Shams Univ., 204pp.

Hassan, N.A. and Radwan, S.G. (2008): Population dynamics of Icerya seychellarum (Homoptera: Margaroididae) and Rodalia cardinalis (Coleoptera : Coccinellidae) on persimmon (Diospyros kaki ) at Qalubiya Governorate. Egypt. J. Agric. Res., 86(3):1015-1027.

Helmy, E. I.(2001): Efficiency of certain alternative pesticides local mineral oils against the soft scale, Pulvinaria tenuivalvata (Newstead) infesting sugar-cane at Giza $1^{\text {st }}$ conferences on safe alternative at pesticides for pest management. Assiut Univ., 91-98.

Helmy. E.I;. Hassan, N.A; EL-Imery, S.M and Haris, H.M. (2001): Miscible oils, IGR. and their Joint effect as promising safe alterative pesticides control against Sacharalecanium krugeri (Zehnter) infesting sugar-cane at Qena Governorate, Egypt $.1^{\text {st }}$ Conf. on Safe Alternative of Pesticides for Pest. Management, Assiut Univ., Egypt; 99-105.

Helmy, S.M.Y. (2000): Ecological studies on the black parlatoria scale, Parlatoria ziziphus (Lucas) (Homoptera : Diaspididae) and its natural enemies in Egypt. M.Sc. Thesis, Fac. Agric., Cairo Univ., Egypt, 146 pp.

Hendawy, A.S.A. (1999): Studies on certain natural enemies of scale insects attacking guava trees at Kafr El-Sheik Governorate. Ph.D. Thesis, Fac. Agric., Tanta Univ., $145 \mathrm{pp}$.

Kasim, Y.I.S. (1995): Studies on some pests of Superfamily Coccoidea infesting fruit trees. Ph.D. Thesis, Fac. Agric., Minufiya Univ., Egypt, 132 pp.

Kreiter, P.; Pinet, C.; Pains, A; Dijoux, L.; Cravedi, P.; Hartfield, C. and Mazzoni, E. (1997) : Study on the biological cycle of the white scale of peach, Pseudaulacaspis pentagona (Targioni-Tozzetti) (Homoptera, Diaspididae) and its natural enemies in Emilie, Romagne (Italy). Integrated plant protection in stone fruit. Proceedings of the Meeting at Zaragoza, Spain, 24-26 September 1996. Bulletin OILB SROP., 20: 6, 14-20.

Nada, M. S. (1999): Studies on the utilization of biodiversity of entomopathogenic fungi against sucking insects abundant in tropical Africa. M.Sc. Thesis, Cairo Univ., 146 pp.

Radwan, S.G. (2003): Toxicologicdal studies on some scale insects infesting mango and guava trees. Ph.D. Thesis, Fac. Agric., Cairo Univ., 221pp.

Salama, H.S.; Abdel Salam, A.L.; Donia, A. and Negahed, M.I. (1985): Studies on the population and distribution pattern of Parlatoria zizyphus (Lucas) in citrus orchards in Egypt. Insect. Sci. Appl., 6(1):43-47.

Salama, H. S. and Hamdy, M. K. (1974): Studies on populations on two scale insects infesting fig trees in Egypt (Coccoidea). Zeitschrift für Angewandte Entomologie, 75(1-4): 200-204. 
Serag, S.A. (1997): Studies on biological control of some piercing and sucking insects. M.Sc. Thesis, Fac. Agric., Al-Azhar Univ., Egypt, 136pp.

Sweilem, S.M.; El-Bolok, M.M. and Abdel-Aleem R.Y. (1985): Effect of different levels of trees, different cardinal directions tree core and leaf surface on the distribution of Parlatoria zizyphus (Lucas) in correlation with the year seasons. Bull. Soc. Entomol. Egypte, 65:289-299.

Tawfik, M. H. and Mohammad, Z. K. (2004): Ecological studies of two scale insects (Hemiptera, Coccoidea) on Morus alba in Egypt. Bollettino di Zoologia Agraria e di Bachicoltura, 33: (3): 267-273.

Willcocks, F.C. (1922): A survey of the more important insects and mites of Egypt with notes on life history habits natural enemies and suggestions for control. Sult. Agric. Sec., Bull. 1:169 pp.

\section{ARABIC SUMMARY}

$$
\begin{aligned}
& \text { الحثرات القشرية الثائعة في مصر } \\
& \text { نجوى علي حسن و سوسن جاب الله رضوان و أمنية محمد نبيل الصحن }
\end{aligned}
$$

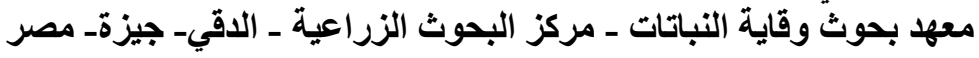

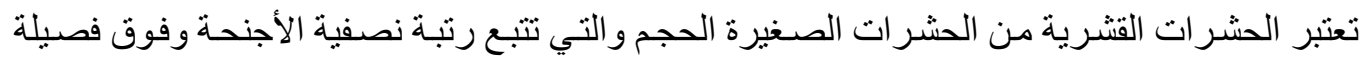
Coccoidea

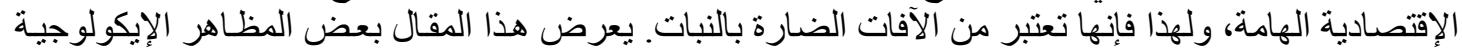

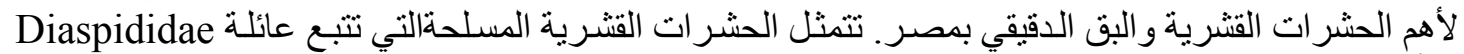

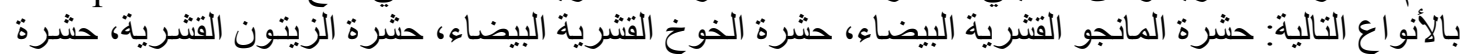

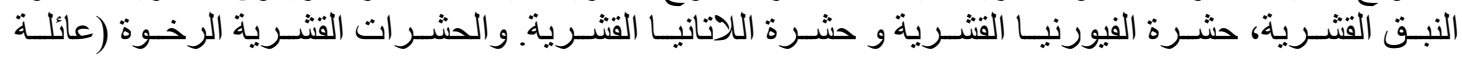

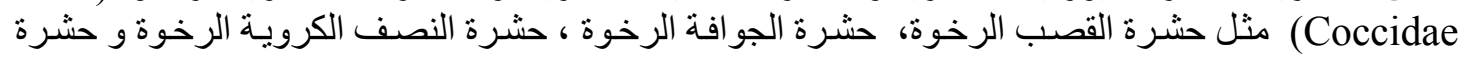

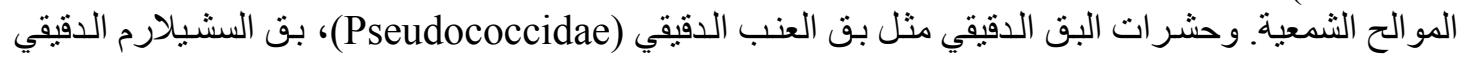
(Monophlebidae) (Asterolecaniidae عائلة) 